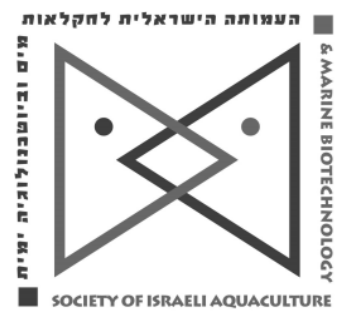

The IJA appears exclusively as a peer-reviewed on-line open-access journal at http://www.siamb.org.il. To read papers free of charge, please register online at registration form.

Sale of IJA papers is strictly forbidden.

\title{
Establishment of a Multiplex PCR Assay to Detect Five Major Freshwater Bacteria
}

\author{
Weihua Gao ${ }^{1,2}{ }^{\prime}$, Kete $\mathrm{Ai}^{1{ }^{1},}$, Kai Luo ${ }^{1}$, Tinghua Huang ${ }^{1}$, Min Yao ${ }^{1}$, \\ Wei Hu ${ }^{1}$, Liu Fang ${ }^{1}$, Zhitao $\mathrm{Qi}^{1}$, Qiaoqing $\mathrm{Xu}^{1,2}$ * \\ ${ }^{1}$ Engineering Research Center of Ecology and Agricultural Use of Wetland, \\ Ministry of Education, Yangtze University, Jingzhou 434024, China \\ 2 School of Animal Science, Yangtze University, Jingzhou, 434020, China \\ $\Delta$ The two authors contributed equally.
}

Keywords: multiplex PCR; freshwater bacteria; detection

\begin{abstract}
A multiplex polymerase chain reaction (mPCR) method for simultaneous detection of Aeromonas hydrophila, Streptococcus agalactiae, Klebsiella pneumoniae, Edwardsiella tarda, and E. ictalur was developed to rapidly and accurately identify the five most common bacteria that infect aquatic animals. The expected amplicons for ahe2 gene of $A$. hydrophila, cpsE gene of $S$. agalactiae, khe gene of $K$. pneumoniae, mukF gene of E.tarda, and the serC gene of E. ictaluri were $853 \mathrm{bp}, 685 \mathrm{bp}, 428 \mathrm{bp}, 356 \mathrm{bp}$, and $124 \mathrm{bp}$, respectively. In the single PCR assays, the minimum detectable DNA contents were $13.2 \mathrm{pg}$ for A. hydrophila, $27.4 \mathrm{pg}$ for S. agalactiae, $1.95 \mathrm{pg}$ for $K$. pneumoniae, $1.63 \mathrm{pg}$ for $E$. tarda, $1.02 \mathrm{pg}$ for E. ictalur. The detection limits of the multiplex PCR were $0.66 \mathrm{ng}, 1.91 \mathrm{ng}, 0.68 \mathrm{ng}$, $0.41 \mathrm{ng}, 0.71 \mathrm{ng}$ for $A$. hydrophila, S. agalactiae, K. pneumoniae, E. tarda and $E$. ictalur, respectively. The established multiplex PCR is significant for the rapid detection of common pathogenic bacteria of aquatic animals and provides the basis for the diagnosis of fish diseases.
\end{abstract}

* Corresponding author. Tel.: +86 7168066289 ; fax: +86 7168066289 .

Email: xuqiaoqing@yangtzeu.edu.cn 


\section{Introduction}

Bacterial diseases are common worldwide and result in significant economic losses in the fish farming industry. For example, Aeromonas hydrophila is a ubiquitous aquatic microorganism that has been associated with hemorrhagic septicemia. Infections by $A$. hydrophila have been reported in Carassius auratus, Parabramis pekinensis, Cirrhinus molitorella, Cyprinus carpio, Hypophthalmichehys molitrix, Aristichthys nobilis, Ctenopharyngodon idellus, Plecoglossus altivelis, Lateolabrax japonicas, Salmo gairdneri, Tilapia nilotica, Ictalurus punctatus, Monopterus albus and Channa striata (Lu, 1992; Duc et al., 2013). Streptococcus agalactiae can cause septicemia and meningoencephalitis, which occurs in Oreochromis spp, Salmo gairdneri, Cyprinus acutidorsalis, Mugil cephalus and Pagrosomus major (Evans et al., 2002). Klebsiella pneumoniae, which causes rot disease, has been reported in Shrimp, Eriocheir sinensis, Hypophthalmichehys molitrix, Anguilla japonica and Trionyx sinensis (Singh and Kulshreshtha, 1992; Tang et al., 2007; Deng et al., 2009; Xu and Shu, 2002). Edwardsiella tarda leads to serious systemic septicemia and affects a wide range of host fish such as Scophthalmus maximus, Paralichthys olivaceus, Ictalurus punctatus, Anguilla anguilla, Pelteobagrus fulvidraco, Astronotus ocellatus, Paralichthys lethostigma, Tilapia nilotica, Hypophthalmichthys molitrix, Scortum barcoo, etc. (Xu and Zhang, 2014; Mohanty and Sahoo, 2007; Park, Aoki, and Jung, 2012). E. ictalur usually produces enteric septicemia, which mainly appears in Ictalurus punctatus and has also been reported in Micropterus salmoniodes, Aristichthys nobilis, Plecoglossus altivelis and Trionyx sinensis (Nagai and Nakai, 2014; Chen, 2004).

Accompanying the rapid development of aquaculture and the expansion of scale breeding, highly intensive aquaculture conditions create serious risks for the spread of contagious diseases in fish populations. Therefore, detection of pathogens from farmed fish is essential for effective fish disease control. Polymerase chain reaction (PCR) is an effective tool for diagnostics. PCR assays have been developed for the rapid detection and identification of microorganisms (Yogananth et al., 2009; Lan et al., 2008; Panangala et al., 2007). However, a multiplex PCR assay is necessary if single primer sets are used on a large number of clinical samples. The objective of the present study was to develop a multiplex PCR (MPCR) assay to detect five major fish pathogens: $A$. hydrophila, S. agalactiae, K. pneumoniae, E. tarda and E. ictalur that cause disease in fish.

\section{Materials and Methods}

Source of the bacteria. Strains of $A$. hydrophila B11, S. agalactiae SF-96-5508, K. pneumoniae B12, NTUH-K2044, E. tarda B79 E. ictalur ETV, Flavobacterium cloumnare EU395799 and Escherichia coli Top10 were kindly supplied by the Institute of Hydrobiology, Chinese Academy of Sciences. Strains of A. hydrophila 1.927, 1.2017, $1.1816,1.1814$ and $S$. agalactiae 1.1481 were purchased from China general microbiological culture collection center. Strains of E. tarda CCTCC AB 2010161, CCTCC AB 206580 and CCTCC AB206591 were purchased from China center for type culture collection. Strains of E. ictalur GXEi0501, GXEi0602 were purchased from Guangxi Veterinary Research Institute. A strain of S. agalactiae 32420 was purchased from the National center for medical culture collections. A strain of S. agalactiae 10465 was purchased from China center of industrial culture collection. $K$. pneumoniae B0094, Aeromonas sobria LD081008A, Pseudomonas fluorescens B0115 and Staphylococcus aureus B0125 were purchased from the national aquatic pathogen library, Shanghai Ocean University.

Genomic DNA extraction. Bacteria were inoculated into tryptic soy broth (TSB). $A$. hydrophila, S. agalactiae, K. pneumoniae, E. tarda, E. coli, A. sobria, P. fluorescens and S. aureus were incubated at $37^{\circ} \mathrm{C}$ for $24 \mathrm{~h}, E$. ictalur was incubated at $28^{\circ} \mathrm{C}$ for $48 \mathrm{~h}$. F. cloumnare was incubated in Shieh at $25^{\circ} \mathrm{C}$ for $48 \mathrm{~h}$. All the cultures were incubated and shaken at $200 \mathrm{rpm}$ in an orbital incubator. The bacteria were harvested by centrifugation at $12000 \mathrm{~g}$ for $1 \mathrm{~min}$, and the supernatant was discarded. DNA was extracted from the cell pellets of all samples following the instructions of the bacteria genomic DNA extraction kit (TIANGEN, China). 
Primer design. Target sequences of the ahe2 gene of $A$. hydrophila and the cPsE gene of $S$. agalactiae were downloaded from the National Centre for Biotechnology Information (NCBI). Specific primers corresponding to each bacterium were designed with primer premier 5.0. Primers for the khe gene of $K$. pneumoniae, the mukF gene of E. tarda, the serC gene of E. ictalur described by He et al., 2012; Jiang et al., 2008; Liu et al., 2013 (Table 1).

Table 1. Specific primer and their target genes for the bacteria used in this study

\begin{tabular}{|c|c|c|c|}
\hline Bacteria & Primers & Target gene & Size $(b p)$ \\
\hline \multirow{2}{*}{$\begin{array}{l}\text { Aeromonas } \\
\text { hydrophila }\end{array}$} & F:GGGCAATGACCTCAACCTC & \multirow{2}{*}{$\begin{array}{l}\text { Serine protease } \\
(\text { ahe2) }\end{array}$} & \multirow[t]{2}{*}{853} \\
\hline & R:CGAGGAGGTGCCGTTCAT & & \\
\hline \multirow{2}{*}{$\begin{array}{l}\text { Streptococcus } \\
\text { agalactiae }\end{array}$} & F:TTATATCGCTGTCTGTATCTTGGACT & \multirow[t]{2}{*}{ Capsule ( $c p s E)$} & \multirow[t]{2}{*}{685} \\
\hline & $\begin{array}{l}\text { R:GCGTGTTCCTACTAAACTCATATCAC } \\
\text { C }\end{array}$ & & \\
\hline \multirow{2}{*}{$\begin{array}{l}\text { Klebsiella } \\
\text { pneumoniae }\end{array}$} & F: TGATTGCATTCGCCACTGG & \multirow{2}{*}{$\begin{array}{l}\text { haemolysin } \\
\text { (khe) }\end{array}$} & \multirow[t]{2}{*}{428} \\
\hline & R: GGTCAACCCAACGATCCTG & & \\
\hline Edwardsiella tarda & $\begin{array}{l}\text { F:TTGCTGGCTATCGCTACCCTT } \\
\text { R:AACTCATCGCCGCCCTCTTCT }\end{array}$ & mukF & 356 \\
\hline $\begin{array}{l}\text { Edwardsiella } \\
\text { ictalur }\end{array}$ & $\begin{array}{l}\text { F: CATGATAATACCCGGTGTTGG } \\
\text { R: GTATTGCTGGGGAACAACTC }\end{array}$ & $\begin{array}{l}\text { Phosphoserine } \\
\text { transaminase } \\
\text { (serC) }\end{array}$ & 124 \\
\hline
\end{tabular}

Reaction conditions. The optimized PCR was set up in a $25 \mu \mathrm{L}$ reaction mixture comprising $2.5 \mu \mathrm{L}$ of $10 \times$ Taq Buffer, $2 \mu \mathrm{L}$ of $\mathrm{MgCl}_{2}(25 \mathrm{mM}), 2 \mu \mathrm{L}$ of dNTP $(2.5 \mathrm{mM}), 1$ $\mu \mathrm{L}(10 \mu \mathrm{M})$ each of forward and reverse primers, $0.25 \mu \mathrm{L}$ of rTaq DNA polymerase (5 $\mathrm{U} / \mu \mathrm{L}$, NovoGene, China), $1 \mu \mathrm{L}$ of DNA and nuclease free water to $25 \mu \mathrm{L}$.

In the single PCR assays, the cycling conditions consisted of an initial denaturation $\left(95^{\circ} \mathrm{C}\right.$ for $3 \mathrm{~min})$, followed by 35 cycles of denaturation $\left(95^{\circ} \mathrm{C}, 30 \mathrm{~s}\right)$, primer annealing $\left(59^{\circ} \mathrm{C}\right.$ for the ahe2 gene of $A$. hydrophila and the cpsE gene of $S$. agalactiae, $57^{\circ} \mathrm{C}$ for the khe gene of $K$. pneumoniae and the serC gene of $E$. ictalur, $60^{\circ} \mathrm{C}$ for the mukF gene of $E$. tarda, $30 \mathrm{~s}$, respectively.), and extension $\left(72^{\circ} \mathrm{C}, 1 \mathrm{~min}\right)$. After a final extension $\left(72^{\circ} \mathrm{C}, 10\right.$ $\mathrm{min})$, the PCR products were held at $4^{\circ} \mathrm{C}$. The reaction products were checked by $2 \%$ agarose gel electrophoresis.

In the $\mathrm{mPCR}$ assay, the primer annealing was set at $59^{\circ} \mathrm{C}, 30 \mathrm{~s}$, the other cycling conditions were same as the single PCR assay.

Specificity analysis. The five primer sets were used with the specific DNA or with mixed DNAs from other bacteria to test their specificity.

Sensitivity analysis. The genomic DNA contents were serially diluted by 5 or 10 times and subjected to PCR amplification. The minimum concentrations of DNAs were considered as the sensitivity of $\mathrm{m}$-PCR detection.

Fish tissue analysis. Genomic DNA of liver, spleen, and muscle tissue from Cyprinus carpio was extracted and mixed with bacterial DNA of the five bacterial pathogens as simulated diseased samples. Following m-PCR amplification and detection, the mixed DNAs were evaluated in practice.

\section{Results}

Primer specificity. Based on the designed primer sets, the specificities of each set against bacterial DNAs obtained from A. hydrophila, S. agalactiae, K. pneumoniae, E. tarda, E. ictalur were examined. For all primer pairs, only a band for the specific bacteria appeared (Fig. 1a-b). When DNA from other bacteria strains was evaluated, no bands were visible on gel electrophoresis (Fig. 1C). 

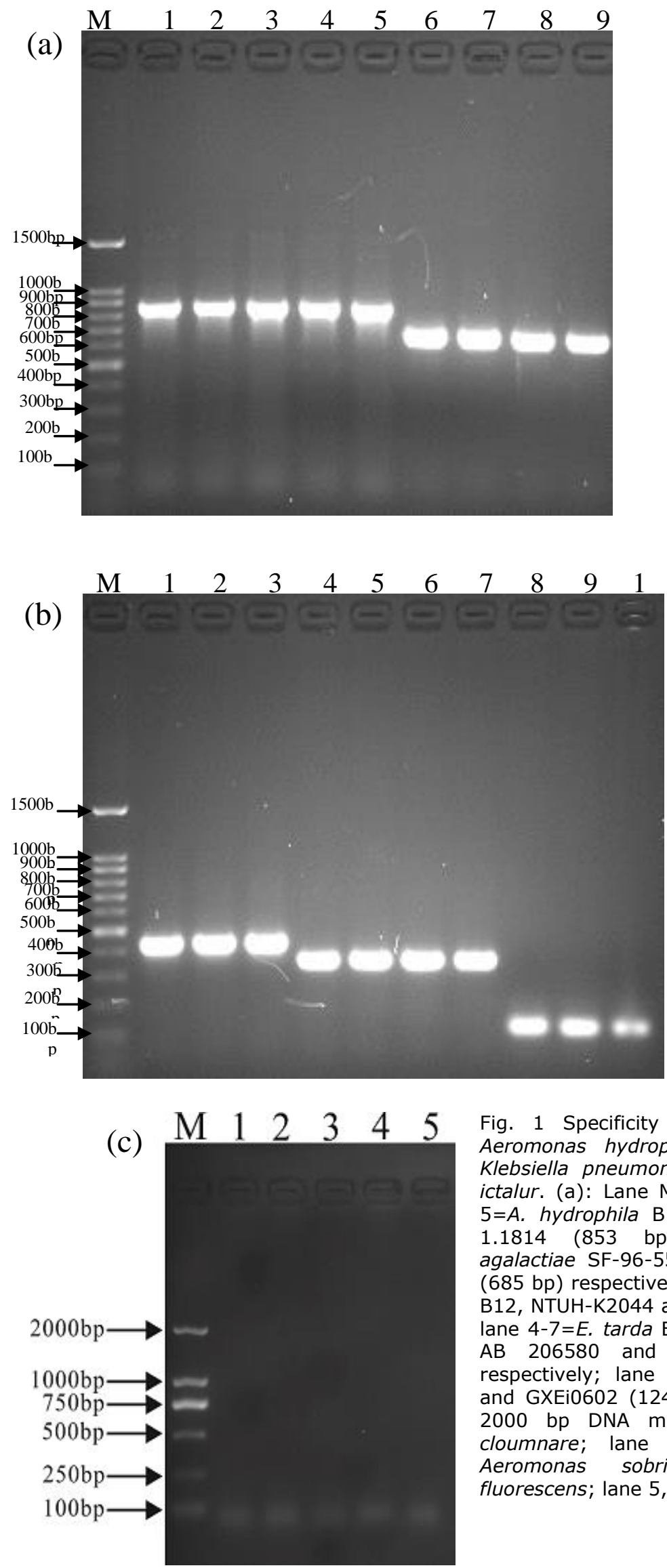

Fig. 1 Specificity of single PCR of DNA from Aeromonas hydrophila, Streptococcus agalactiae, Klebsiella pneumoniae, Edwardsiella tarda and E. ictalur. (a): Lane M, 100 bp DNA marker; lane 1$5=A$. hydrophila $\mathrm{B} 11,1.927,1.2017,1.1816$ and 1.1814 (853 bp) respectively; lane $6-9=S$. agalactiae SF-96-5508, 1.1481, 32420 and 10465 (685 bp) respectively; (b): lane $1-3=K$. pneumoniae B12, NTUH-K2044 and B0094 (428 bp) respectively; lane 4-7=E. tarda B79, CCTCC AB 2010161, CCTCC AB 206580 and CCTCC AB206591 (356 bp) respectively; lane $8-10=E$. ictalur ETV, GXEi0501 and GXEi0602 (124 bp) respectively; (c): Lane M 2000 bp DNA marker; lane 1, Flavobacterium cloumnare; lane 2, Escherichia colI; lane 3, Aeromonas sobria; lane 4, Pseudomonas fluorescens; lane 5, Staphylococcus aureus. 
Detection sensitivity. After diluting the target DNA by 5 or 10 times, the minimum detectable DNA contents were determined as $13.2 \mathrm{pg}$ for A. hydrophila (Fig. 2a), $27.4 \mathrm{pg}$ for S. agalactiae (Fig. 2a), 1.95 pg for K. pneumoniae (Fig. 2b), 1.63 pg for E. tarda (Fig. 2c), $1.02 \mathrm{pg}$ for $E$. ictalur (Fig. 2d) in the single PCR reactions. The detection limits of the multiplex PCR was in the range of $0.66 \mathrm{ng}, 1.91 \mathrm{ng}, 0.68 \mathrm{ng}, 0.41 \mathrm{ng}, 0.71 \mathrm{ng}$ for $A$. hydrophila, S. agalactiae, K. pneumoniae, E. tarda and E. ictalur (Fig. 2d).
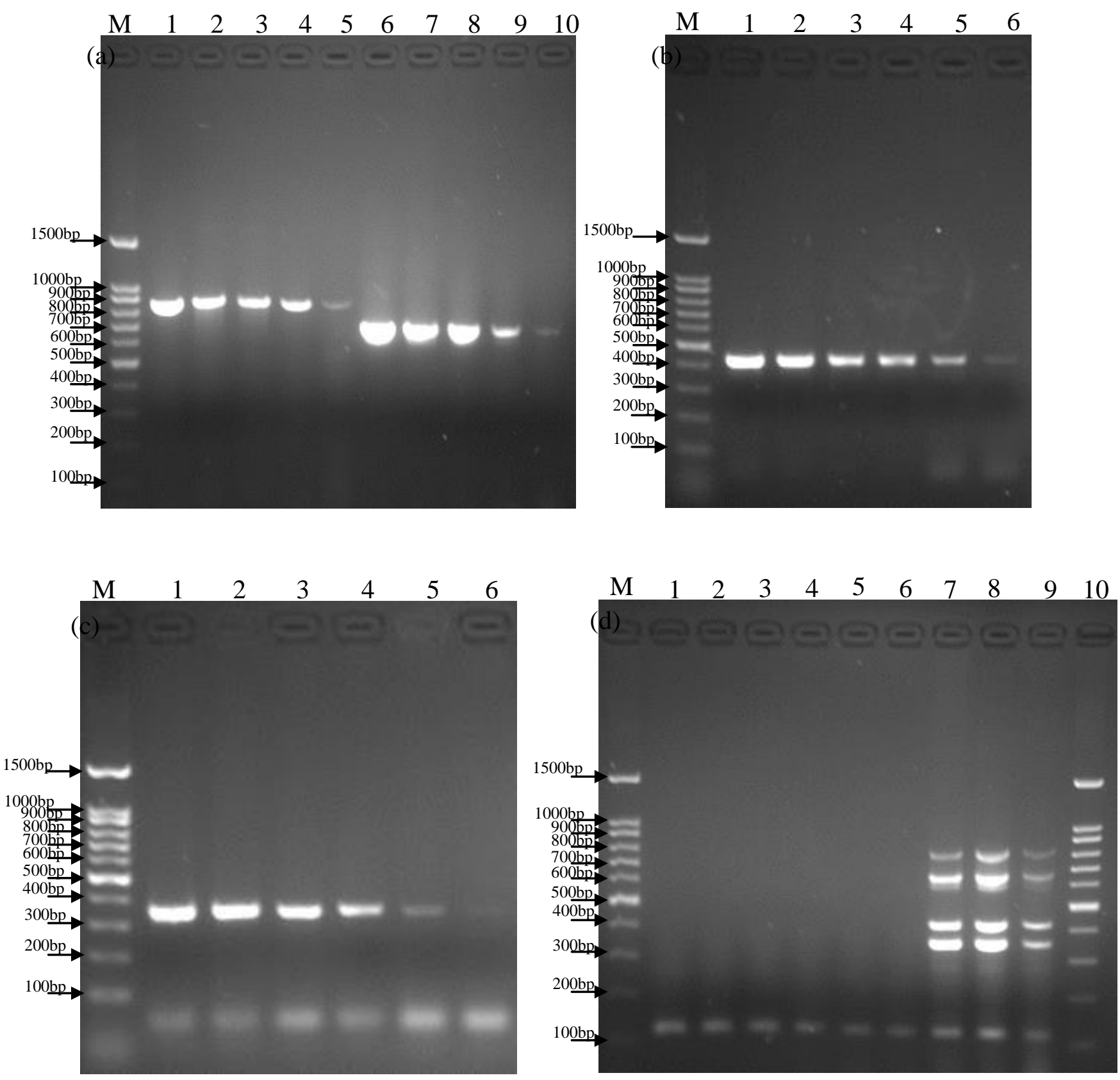

Fig. 2 Sensitivity of the detection of $A$. hydrophila, S. agalactiae, K. pneumoniae, E. tarda and E. ictalur by single PCR and mPCR. (a): Lane M, 100 bp DNA marker; lanes $1-4=1$ to $10^{-3}$ dilutions of A. hydrophila, respectively; lane 5 , the $2 \times 10^{-4}$ dilution of $A$. hydrophila; lanes $6-10=1$ to $10^{-4}$ dilutions of $S$. agalactiae, respectively; (b): Lane $M, 100$ bp DNA marker; lanes $1-5=1$ to $10^{-4}$ dilutions of $K$. pneumoniae; lane 6 , the $2 \times 10^{-5}$ dilution of $K$. pneumoniae ; (c): Lane M, 100 bp DNA marker; lanes $1-5=1$ to $10^{-4}$ dilutions of $E$. tarda, respectively; lane 6 , the $2 \times 10^{-5}$ dilution of E. tarda; (d): Lane M, 100 bp DNA marker; lanes $1-6=1$ to $10^{-5}$ dilutions of $E$. ictalur, respectively; lanes $7-9=1$ to $10^{-2}$ dilutions of $A$. hydrophila, S. agalactiae, K. pneumoniae, E. tarda and E. ictalur, respectively. 
MPCR. The genomic DNAs of the five bacterial pathogens were mixed to see whether single or multiple species of pathogen were effectively amplified. The results demonstrated that all combinations of the pathogenic DNA could be detected successfully (Fig. 3).
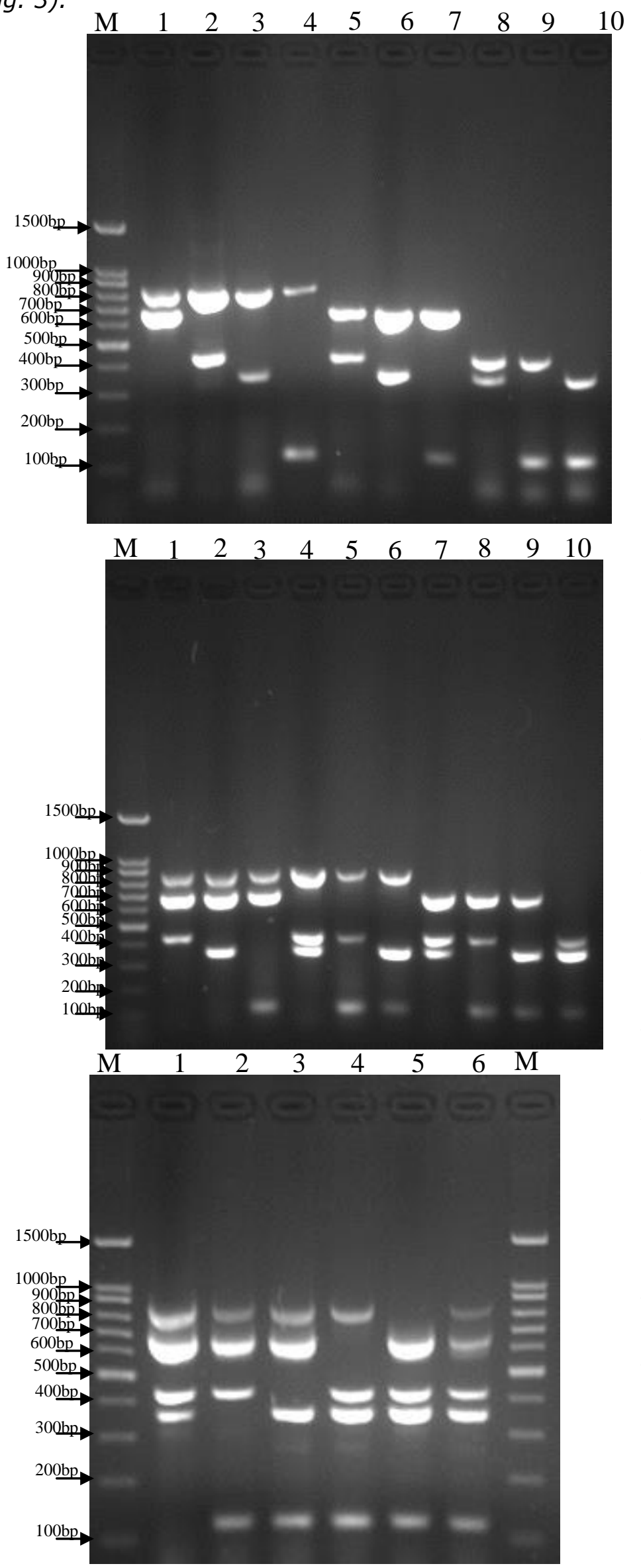

Fig. 3 The results of $\mathrm{mPCR}$ amplification of genomic DNA from two, three, four or five bacteria with different combinations of target PCR templates. (a): Lane M, 100 bp DNA marker; lane $1, A$. hydrophila and $S$. agalactiae; lane 2, A. hydrophila and $K$. pneumoniae; lane $3, A$. hydrophila and $E$. tarda; lane 4, A. hydrophila and E. ictalur; lane 5, S. agalactiae and $K$. pneumoniae; lane 6, S. agalactiae and E. tarda; lane 7, $S$. agalactiae and $E$. ictalur; lane $8, K$. pneumoniae and $E$. tarda; lane 9, $K$. pneumoniae and $E$. ictalur; lane 10, $E$. tarda and E. ictalur; (b): Lane M, 100 bp DNA marker; lane 1, A. hydrophila, S. agalactiae and $K$. pneumoniae; lane 2, A. hydrophila, S. agalactiae and E. tarda; lane 3, A. hydrophila, S. agalactiae and E. ictalur; lane 4, $A$. hydrophila, $K$. pneumoniae and E. tarda; lane 5, A. hydrophila, K. pneumoniae and E. ictalur; lane 6, A. hydrophila, E. tarda and E. ictalur; lane 7, S. agalactiae, $K$. pneumoniae and E. tarda; lane $8, S$. agalactiae , K. pneumoniae and E. ictalur; lane 9, S. agalactiae, E. tarda and E. ictalur; lane $10, K$. pneumoniae, E. tarda and E. ictalur; (c): Lane M, 100 bp DNA marker; lane $1, A$. hydrophila, $S$. agalactiae, K. pneumoniae and E. tarda; lane 2, A. hydrophila, S. agalactiae, $K$. pneumoniae and E. ictalur; lane $3, A$. hydrophila, S. agalactiae, E. tarda and $E$. ictalur; lane 4, $A$. hydrophila, $K$. pneumoniae, E. tarda and E. ictalur; lane 5, S. agalactiae, K. pneumoniae, E. tarda and E. ictalur; lane 6, A. hydrophila, S. agalactiae, K. pneumoniae, E. tarda and $E$. ictalur. 
Fish tissue. Following mPCR amplification and detection with the mixed DNAs, the diagnostic efficiency was maintained with predicted amplicons, which suggests that no interfering effects occurred (Fig. 4).

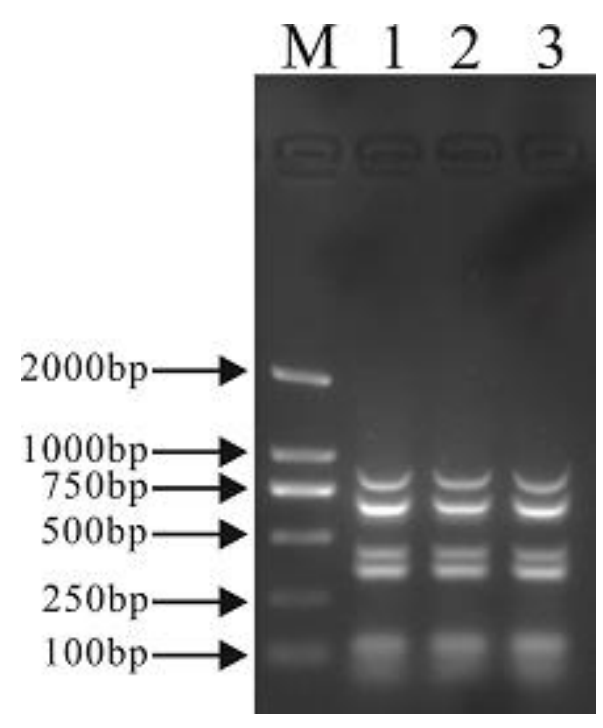

Fig. 4 The results of mPCR amplification of genomic DNA from five bacteria in combination with genomic DNA from Cyprinus carpio tissue. Lane M, 2000 bp DNA marker; lane 1, mixture of genomic DNA from the target bacteria and Cyprinus carpio liver ; lane 1, mixture of genomic DNA from the target bacteria and Cyprinus carpio spleen; lane 1, mixture of genomic DNA from the target bacteria and Cyprinus carpio muscle.

\section{Discussion}

The aim of this study was to develop a simple and sensitive novel PCR method for simultaneous identification of common pathogens that cause disease in fish. Primers were designed to uncover different length fragments of $853 \mathrm{bp}, 685 \mathrm{bp}, 428 \mathrm{bp}, 356 \mathrm{bp}$, and 124 bp from $A$. hydrophila, S. agalactiae, K. pneumoniae, E.tarda, and E. ictaluri. The primer specificities of each set were examined. The size of PCR products was as expected with no additional fragments from target pathogens (Fig. 1). Detection sensitivity was important to the efficiency of PCR amplification. After serially diluting the target DNA by 5 or 10 times, the minimum detectable DNA contents were determined as $0.66 \mathrm{ng}$ for $A$. hydrophila, $1.91 \mathrm{ng}$ for $S$. agalactiae, $0.68 \mathrm{ng}$ for $K$. pneumoniae, $0.41 \mathrm{ng}$ for E. tarda, $0.71 \mathrm{ng}$ for E. ictalur in the multiplex PCR (Fig. 2). These results suggest that the established multiplex PCR is sensitive to the rapid detection common pathogenic bacteria of aquatic animals.

Traditional methods of diagnosis are carried out by culturing bacteria on agar plates followed by biochemical characterization (Zhang et al., 2010). Some disadvantages of these techniques are: the length of time taken, which could delay effective treatment of fish diseases; and compared with PCR assay, it is not accurate to detect pathogenic bacteria by colonies morphology and bacterial characteristics, etc.

The molecular assay using real-time quantitative PCR could be a rapid and sensitive diagnostic tool to detect pathogens (Bilodeau et al., 2003; Griffin et al., 2013) however, this requires high quality equipment, high costs, and complex operation, which makes it non-optimal for the detection of bacteria pathogens. The specific, easy to use, low-cost mPCR system developed in this study could simultaneously detect $A$. hydrophila, $S$. agalactiae, K. pneumoniae, E. tarda and E. ictalur.

PCR has been widely applied to detect various viruses and bacteria (Pollard et al., 1990; Lan et al., 2008; Sakai et al., 2007). Bacterial diseases may be diverse and depend on the farmed species, and culture area; therefore it is difficult to assess disease outbreaks using a universal diagnostic measure or procedure, especially when newly emerging diseases are probable. And it would be undetected if two or several pathogenic bacteria affected the fish. To avoid wasting time using a single PCR, an MPCR assay was 
developed for simultaneous detection of $A$. hydrophila, S. agalactiae, K. pneumoniae, $E$. tarda and $E$. ictalur. This new MPCR assay is important for the diagnosis of fish diseases.

Identification of virulence genes is useful for the diagnosis of fish disease. Pathogenic bacteria may have virulence genes that are absent in nonpathogenic bacteria. Virulence genes may also be present in both pathogenic and nonpathogenic bacteria, but may be functional only in pathogenic ones (Srinivasa Rao et al., 2003). The ahe2 gene of $A$. hydrophila, the cPsE gene of $S$. agalactiae, the mukF gene of E. tarda, the serC gene of E. ictalur are virulence genes (Li et al., 2011; Schaffner et al., 2014; Srinivasa Rao et al., 2003; Rodrigues et al., 2006). The mukF gene of $E$. tarda was present only in virulent and not in avirulent strains, indicating that they are specific to pathogenic $E$. tarda (Srinivasa Rao et al., 2003). However the ahe2 gene of $A$. hydrophila, the cpsE gene of $S$. agalactiae and the serC gene of E. ictalur are associated with their toxicity (Yu et al., 2005; Rodrigues et al., 2006). If using avirulence genes to diagnose diseased fish that were infected with nonpathogenic bacteria, the diagnosis would be incorrect. Detection of these virulence genes will be useful for diagnosing the cause of fish diseases as they emerge.

\section{Acknowledgments}

This study was supported by Engineering Research Center of Ecology and Agricultural Use of Wetland, Ministry of Education (KF201611), Hubei provincial department of Education (B2016035), Open fund from Institute of New Rural Development, Hubei Province (2013CXJ08), Public Welfare Scientific Research Project (201003076), National water pollution control and management technology major projects (2012ZX07101-002), National Science and Technology Support Program (2013BAD20B06). We would like to thank Prof. Li Aijua of the Prof. Li Aihua, Institute of Hydrobiology, Chinese Academy of Sciences who kindly supplied some of the various strains of bacteria used.

\section{References}

Bilodeau A. L., G. C. Waldbieser, J. S. Terhune, D. J. Wise, and Wolters W. R. 2003. A real time polymerase chain reaction assay of the bacterium Edwardsiella ictaluri in channel catfish. J Aquat Anim Health, 15:80-86.

Chen C. Z. 2004. Edwardsiella and Edwardsiellasis of fish (Summary). J Hebei Normal University of Sci Technol., 18:70-76.

Deng G. C, X. Luo, X. Y. Jiang, L. H. Liu, M. H. Lin, Y. A. Peng and Liao G. L. 2009. Separation and identification of the eel Klebsiella pneumoniae. J Shanghai Ocean University, 18:2193-2197.

Duc P. M., T. N. Tuan and Hatai K. 2013. Aeromonas hydrophila infection in fingerlings of snakehead Channa striata in viet nam. Fish pathol., 48:48-51.

Evans, J. J., P. H. Klesius, P. M. Gilbert, C. A. Shoemaker, M. A. Al. Sarawi, J. Landsberg, R. Duremdez, A. Al. Marzouk and Zenki S. Al. 2002. Characterization of b-haemolytic Group B Streptococcus agalactiae in cultured seabream, Sparus auratus L., and wild mullet, Liza klunzingeri (Day), in Kuwait. J Fish Dis., 25:505-513.

Griffin M. J., A. E. Goodwin, G. E. Merry, M. R. Liles, M.A. Williams, C. Ware and Waldbieser G. C. 2013. Rapid quantitative detection of Aeromonas hydrophila strains associated with disease outbreaks in catfish aquaculture. J Vet Diagnostic Investigation, 25:473-481.

He J. Y., J. F. Qiu, M. Y. Liu, X. J. Yan, L. Y. Li, Z. B. Guo and Zhou D. S. 2012. Polymerase Chain Reaction Analysis for Detecting Highly Virulent Serotypes of Klebsiella pneumoniae. Letters in Biotechnology, 23:554-557.

Jiang Y., S. S. Li, S. K. Wang, L. X. Guo, S. X. Jiang, W. B. Chen and Shao B. Y. 2008. Detection of the Virulence Genes of Pathogenic Edwardsiella Tarda by PCR Assay. J Chinese Institute of Food Sci Technol., 8: 123-129.

Lan J., X. H. Zhang, Y. Wang, J. Chen and Han Y. 2008. Isolation of an unusual strain of Edwardsiella tarda from turbot and establish a PCR detection technique with the gyrB gene. J Appl Microbiol., 105:644-651.

Li J., X. L. Zhang, Y. J. Liu and C. Lu P. 2011. Development of an Aeromonas hydrophila infection model using the protozoan Tetrahymena thermophile. FEMS Microbiol Lett, 316:160-168. 
Liu T. Q., G. J. Huang, Y. P. Liu and Xiao D. 2013. Development of a conventional PCR method for the detection of Edwardsiella ictaluri. Freshwater Fisheries, 43:76-79.

Lu C. P. 1992. Pathogenic Aeromonas hydrophila and the fish diseases caused by it. J. Fish. China, 16:282-288.

Mohanty, B. and Sahoo P. 2007. Edwardsiellosis in fish: a brief review. J. Biosci., 32:1331-1344.

Nagai A. and Nakai T. 2014. Water Temperature Effect on Edwardsiella ictaluri Infection of Ayu Plecoglossus altivelis. Fish Pathol., 4: 61-63.

Panangala V. S., C. A. Shoemaker, V. L. van Santen, K. Dybvig and Klesius P. H. 2007. Multiplex-PCR for simultaneous detection of 3 bacterial fish pathogens, Flavobacterium columnare, Edwardsiella ictaluri, and Aeromonas hydrophila. Dis Aquat Organ., 74: 199-208.

Park, S. B., T. Aoki, and Jung T. S. 2012. Pathogenesis of and strategies for preventing Edwardsiella tarda infection in fish. Vet. Res., 43:1-11.

Pollard D. R., W. M. Johnson, H. Lior, S. D. Tyler, Rozee K. R. 1990. Detection of the aerolysin gene in Aeromonas hydrophila by polymerase chain reaction. J Clin Microbiol., 28:2477-2481.

Rodrigues F., M. Sarkar-Tyson, S. V. Harding, S. H. Sim, H. H. Chua, C. H. Lin, X. Han, R. K. Karuturi, K. Sung, K. Yu, W. Chen, T. P. Atkins, R. W. Titball and Tan P. 2006. Global Map of Growth-Regulated Gene Expression in Burkholderia pseudomallei, the Causative Agent of Melioidosis. J Bacteriol., 188:8178-8188.

Sakai T., T. Lida, K. Osatomi and Kanai K. 2007. Detection of Type 1 Fimbrial Genes in Fish Pathogenic and Nonpathogenic Edwardsiella tarda strains by PCR. Fish Pathol., 42:115-117.

Schaffner T. O., J. Hinds, K. A. Gould, D. Wüthrich, R. Bruggmann, M. Küffer, K. Mühlemann, M. Hilty and Hathaway L. J. 2014. A point mutation in cpsE renders Streptococcus pneumoniae nonencapsulated and enhances its growth, adherence and competence. BMC Microbiology, 14:210.

Singh, B. R. and Kulshreshtha S. B. 1992. Preliminary Examinations on the Enterotoxigenicity of Isolates of Klebsiella pneumoniae from Seafoods. Int J Food Microbiol., 16:349-352.

Srinivasa Rao P. S., T. M. Lim and Leung K. Y. 2003. Functional Genomics Approach to the Identification of Virulence Genes Involved in Edwardsiella tarda. Infect Immun., 71:1343-1351.

Tang Y., F. Zhang, H. C. Sun, X. X. Geng, Z. Tu and Wan Y. J. 2007. Isolation and identification of Klebsiella pneumoniae from silver carp. J Southwest University (Natural Science Edition), 29:702-706.

Xu H. S. and Shu M. A. 2002. Studies on the pathogens of the Klebsiella pneumoniae disease of Trionyx sinensis. Zhejiang University (Science Edition), 29:702-706.

Xu T. T. and Zhang X. H. 2014. Edwardsiella tarda: an intriguing problem in aquaculture. Aquaculture, 431:129-135.

Yogananth N., R. Bhakyaraj, A. Chanthuru, T. Anbalagan and Mullai Nila K. 2009. Detection of Virulence Gene in Aeromonas hydrophila Isolated from Fish Samples Using PCR Technique. Global J Biotech Biochem., 4:51-53.

Yu H. B., Y. L. Zhang, Y. L. Lau, F. Yao, S. Vilches, S. Merino, J. M. Tomas, S. P. Howard and Leung K. Y. 2005. Identification and Characterization of Putative Virulence Genes and Gene Clusters in Aeromonas hydrophila PPD134/91. Appl Environ Microbiol., 71:4469-4477.

Zhang Q., W. Song and Chen J. 2010. Isolation and Identification of Edwardsiella ictaluri from Channel Catfish. J Anhui Agricult Sci., 38:20121-20122. 